\title{
HUMOR PARA UNA NUEVA ETAPA HISTÓRICA: MANICÒMIC, DE TRICICLE
}

\author{
Juan A. Ríos CARRATALÁ \\ Universidad de Alicante
}

El humor tiene fecha de caducidad. Dicho así, tan rotundo, puede parecer una barbaridad, sobre todo a quienes disfrutamos con algunos clásicos que todavía nos hacen sonreír. Algo similar pensarán quienes hayan analizado, desde diferentes perspectivas teóricas, un fenómeno tan esquivo como es el humor. Tienden a establecer constantes universales, válidas sin duda para comprender la permanencia de lo que varía más en lo aparente que en lo fundamental. De acuerdo, pero también hay una realidad constatada por la mayoría de nosotros: a la hora de reírnos, lo hacemos más intensamente con lo coetáneo.

En nuestra memoria del humor pueden figurar Plauto, Molière, Cervantes..., como modelos que dignifican una reacción que a veces nos cuesta reivindicar en términos académicos. Junto a ellos, no obstante, es probable que permanezca el recuerdo de unas carcajadas provocadas por un humorista televisivo, una divertida comedia de relativo valor cinematográfico o un gag, uno muy concreto que, por razones subjetivas, hemos contado reiteradas veces a amigos y familiares. $\mathrm{Si}$ hablamos desde la memoria, debemos dar entrada a manifestaciones humorísticas que no responden al canon académico, se sitúan en un caos ajeno a cualquier jerarquía y cobran mayor fuerza conforme responden a una realidad cercana en el tiempo, insertada de manera directa en nuestra propia experiencia vital. Reír hasta llorar, éxtasis de una comicidad que no debe ser separada del humor, es una experiencia que como lector o espectador suele remitirnos a una ficción coetánea, sin menoscabo de los clásicos. 
Esta circunstancia nos debiera llevar a prestar más atención, desde un punto de vista académico, a los humoristas contemporáneos. Entre otras razones, porque nos ayudan a conocernos y a revelar claves de una época cuya cercanía dificulta su análisis. Lo he intentado hacer, desde una perspectiva personal, en La memoria del humor', donde recurro a ejemplos que, en buena medida, son los disfrutados por un sector de mi generación y coinciden con los inicios de la etapa democrática, cuando yo era un estudiante universitario. No es una casualidad. Cualquiera puede empezar a sonreir a los sesenta años con la obra de un recién descubierto humorista. Sería una envidiable prueba de vitalidad, al menos desde el punto de vista de la actitud mental. Lo probable, no obstante, es que tendamos a identificarnos con quienes hemos disfrutado en un momento de definición personal como es la juventud. Mi generación soportó los estertores del franquismo, no tuvo demasiadas oportunidades de sonreír en unos años tensos como los de la transición y, llegados los ochenta, cuando la salida de un túnel permitió cierta relajación, empezó a hacerlo con una serie de autores e intérpretes que, también en este campo, marcaron un punto y aparte, poco reconocido por quienes se han ocupado de la cultura de la actual etapa democrática.

¿Quién se acuerda de los humoristas de los últimos años del franquismo, de aquellos que mejor sintonizaban con una época donde los franquistas, mal que nos pese y desde un punto de vista cultural, eran tal vez mayoría? Cuando se habla del vertiginoso cambio cultural que supuso la llegada de la democracia, también habría que incluir la drástica desaparición de algunos nombres cuya popularidad, y hasta reconocimiento, no tenía límites poco antes. Hablemos del teatro. Podríamos citar el ejemplo de Alfonso Paso, que pasó de la omnipresencia en las carteleras de los años sesenta a un olvido que, ya a finales de los setenta. era llamativo. Otros comediógrafos más jóvenes y menos ególatras, como Juan José Alonso Millán, aguantaron en candelero tras la muerte del dictador, gracias al oportunismo de una sátira tan fácil como reaccionaria, propia de unos momentos de cambio donde un sector, muy importante, de los espectadores se aferraba a un pasado asumido con bastante cinismo. Y con ellos, siempre en el ámbito del teatro humorístico, se inició el ocaso de algunos de sus habituales intérpretes, con compañía propia, que agotaban las últimas temporadas de estrenos en Madrid y giras por provincias. Todavía conservaban su público durante la transición, pero envejecido y más dispuesto a reír en el salón comedor frente al televisor. En ese medio algunos encontraron un esporádico refugio, junto con los añorados Tip y Coll y lo más rancio del humor patrio: caricatos, imitadores, chistosos con repertorio de gangosos, mariquitas, baturros, andaluces... Los espectáculos de José

'Alicante, Secretariado de Publicaciones de la Universidad de Alicante, 2005. 
Luis Moreno, con los inefables Hermanos Calatrava, constituyen un magnífico y prolongado ejemplo en este sentido.

Todavía persistía en los escenarios un humor más olvidado en la actualidad. Me refiero al de géneros como las variedades y la revista, cuyo ocaso tras décadas de esplendor era tan definitivo como la vejez de los cómicos, siempre bajitos y hasta enclenques, que acompañaban a la escultural vedette de turno en una relación donde no hace falta hilar fino para averiguar las causas de su comicidad. Algunos pudieron pasar al cine gracias a Mariano Ozores y similares, cuyas películas, por sus limitaciones, tanto nos revelan acerca de unos recursos teatrales propios de unos géneros (sainete, astracán, juguete cómico...) en fase de desaparición o disolución en otros renovados. Los que no encontraron este cobijo tuvieron un triste final del que nadie ha levantado acta, como el de los teatros ambulantes - Teatro Chino, Teatro Argentino...-, donde se combinaba por entonces risas y un destape embutido en medias con carreras, todo en imposible competencia con otros medios, más confortables, cuya oferta era similar.

En cuanto al mejor humor del franquismo, excepción hecha del que se opuso al mismo desde diferentes frentes que apenas cuajaron en lo teatral, casi nada quedó durante la transición. Eran años de un presente acuciante, incompatible con la elegancia y finura de las comedias de Miguel Mihura, Jardiel Poncela, Víctor Ruiz Iriarte, José López Rubio o Edgar Neville, que respondían a una etapa anterior. Ahora, con otra perspectiva, somos capaces de apreciar su aportación que, convenientemente destilada, es un patrimonio común de quienes disfrutamos con un humor alejado de la risotada. Pero, por entonces, casi nadie estaba por la labor, y la cartelera de aquellos años refleja el predominio de un teatro humorístico donde unos desconfiaban de lo que había triunfado antes y otros todavía no habían encontrado su propia línea.

No obstante, quienes andábamos por los veinte años a principios de los ochenta no nos quedábamos a ver la televisión los sábados por la noche, ni acudíamos a las representaciones de un teatro humorístico que nos parecía envejecido o rancio. Valoración que solíamos extender a gran parte del teatro programado en los locales tradicionales, alejados del peculiar ambiente de tantos festivales y lugares variopintos que cobijaron las representaciones teatrales más renovadoras del tardofranquismo y la transición. Supongo que la movida, con su diversidad de manifestaciones, tuvo su peculiar humor, que sólo percibí a través de las primeras películas de Pedro Almodóvar, cuyo recuerdo prefiero no almacenar en mi memoria. Algunos, pocos y un tanto refractarios a la posmodernidad, lo buscábamos por la minoritaria vía teatral, donde empezaban a popularizarse comediógrafos, intérpretes y compañías capaces de mostrar un humor realmente fresco, ajeno a una dictadura ya por fin arrumbada y a una transición que, por definición, se consumió a pasos agigantados. 
Teníamos nuestros antecedentes, propios de una cultura de oposición al franquismo que había reído con grupos del teatro independiente como Tábano, el más proclive a una farsa de clara intención política que tan necesaria nos resultaba. Albert Boadella ya por entonces utilizaba, a veces, el humor en los montajes de Els Joglars. En sus memorias ${ }^{2}$ habla de sí mismo como un bufón, pero como tantos otros autores de la época no apostó por un teatro humorístico de escaso prestigio, a menudo restrictivo o limitado $\mathrm{y}$, tal vez, no perentorio en aquellas circunstancias. Tuvo que pasar algún tiempo y desaparecer determinadas urgencias históricas para que, a principios de los ochenta, surgiera sobre los escenarios un humor nuevo, imaginativo y capaz de marcar una línea con la necesaria continuidad. A pesar, incluso, de la política cultural del PSOE, que en lo teatral se mostró desdeñosa hacia los grupos y autores que, desde la empresa privada, se decantaron por la búsqueda de la sonrisa del público. Algún día habrá que analizar el porqué de esta actitud de la izquierda, política y cultural, hacia el humor de aquellos años. Prejuicios, esnobismo, desdén por el público, culturalismo, vanguardismo como enfermedad infantil..., razones que en cualquier caso apenas se sustentan argumentalmente, aunque tan fuertes se mostraran por la vía de los hechos y resultaran incontestadas en los foros abiertos al debate teatral, que también padeció los efectos de una mayoría absoluta y satisfecha.

Uno de los mejores ejemplos del humor teatral alumbrado en la década de los ochenta fue Tricicle 3 . El grupo catalán inició su andadura en 1979 y obtuvo sus primeros éxitos con Manicòmic (1982) ${ }^{4}$, un espectáculo cuya sencillez y

${ }^{2}$ Memoricas de un bufón, Madrid, Espasa, 2001.

${ }^{3}$ Tricicle carece de una bibliografia crítica en el ámbito académico, salvo una memoria de licenciatura, realizada por Susana Pardo, que tuve la oportunidad de dirigir en el año 2000. También, con su coordinación, supervisé la elaboración de una página electrónica dedicada al grupo y alojada en la Biblioteca Virtual Miguel de Cervantes: www.cervantesvirtual.com. En la misma, se da cuenta de la trayectoria del grupo con documentos y recursos audiovisuales. También se incluye un apartado dedicado a la crítica y la investigación, con las referencias bibliográficas que conocemos acerca de Tricicle, cuyos componentes prestaron una decisiva colaboración.

${ }^{4}$ Sobre el estreno, véanse: Gonzalo Pérez de Olaguer, «Tricicle estrena hoy su Manicómic», El Periódico, 14-XII-1982; Patricia Gabancho, «Un Manicòmic para reír a mandíbula batiente», $A B C, 15-X I 1-1982$; Xabier Fábregas, «Manicomic, un buen espectáculo gestual», La Vanguardia, 16-XII-1982; P. Espinosa Bravo, «Manicomic: espectáculo visual con buen humor», Diarto de Barcelona, 16-XI1-1982; Josep Urdeix, «Manicomic: risa de primera mano», El Correo Catalán, 17-XII-1982; Gonzalo Pérez de Olaguer, «Manicòmic», El Periódico, 20-XII-1982, y Lorenzo López Sancho, «Manicómic, un avance del mimo y la pantomima», $A B C, 29-1 \mathrm{X}-1983$. Dentro de la parquedad de la bibliografía crítica acerca del grupo, cabe destacar los siguientes trabajos: Antonio Fernández Lera, «El Tricicle: objetivo, la risa», El Público, 15 (dic., 1984), pp. 22-23; Marisol Galdón, «Tricicle toma la palabra», Elle, 110 (nov., 1995), pp. 38-42; María Güell, «Tricicle, 20 años sobre ruedas», Blanco y Negro, 4191 (24-X-1999), pp. 48-55; Paco Sánchez Pina, "La humorística trinidad», Escena, 28 (mar., 1996), pp. 12-18, y Rosana Torres, «Tres elásticos triciclos», EPS (12-VI-1988), pp. 73-76. 
oportunidad en el uso de los resortes humorísticos sentaron las bases de la triunfal trayectoria, hasta el presente, de un grupo fundamental para conocer el teatro de la etapa democrática.

No fue un fenómeno aislado, ni mucho menos casual, que Tricicle surgiera en Barcelona, en concreto en torno al Institut del Teatre, donde Carles Sans, Paco Mir y Joan Gracia estudiaban mimo, al tiempo que desarrollaban otras actividades académicas y laborales. El teatro catalán tenía por entonces un perfil bastante diferenciado, y desarrollado en sus aspectos más creativos, que hacía viables iniciativas impensables en el resto del país. Aparte de Els Joglars, podríamos citar grupos como Comediants, Dagoll Dagom, La Cubana, Vol Ras..., sin parangón por sus características en otros ámbitos de la España de aquella época. También cabe recordar la labor por entonces de pedagogos del teatro gestual como Anton Font, Pawel Rouba y Andrzej Leparskl. No me corresponde en este artículo justificar una circunstancia histórica que, a la hora de ser trazada, debiera incluir géneros o manifestaciones como el musical, el mimo, el cabaret, el teatro de calle..., que habitualmente quedan al margen de los estudios académicos y se sitúan en una larga tradición del espectáculo que, en Cataluña, desde principios del siglo XX tiene una importancia peculiar.

Manicòmic fue el espectáculo adecuado para el momento oportuno. Cuando se estrenó, en diciembre de 1982, muchas otras cosas estaban empezando en España, a las que se sumó un humor que no pretendía romper moldes ni ser iconoclasta. Al contrario, Tricicle partía de unas técnicas tradicionales (mimo, pantomima, clown...) y unos referentes temáticos y tipológicos reconocibles para la mayoría de los espectadores, que pronto fueron muchos y de diversa procedencia y edad, todos cautivados por la sencillez y frescura de un tratamiento teatral capaz de alumbrar un humor sin fronteras de ningún tipo.

La imagen de tres jóvenes mimos, en un escenario casi vacío y en un espectáculo cuya austeridad era propia de las carencias de quienes comienzan su andadura artística, no invitaba a pensar en un éxito popular. El mismo también fue posible, preciso es reconocerlo, gracias a circunstancias extrateatrales, como la emisión de un sketch de Manicòmic en un programa televisivo de máxima audiencia, Un, dos, tres..., cuando RTVE era un monopolio. Fue una oportunidad bien aprovechada, capaz de mejorar la suerte de unos jóvenes que hasta entonces sólo habian actuado en modestos locales. No se deslumbraron, permanecieron fieles a su trabajo y evitaron la búsqueda de un éxito tan mayoritario como fugaz. No obstante, para que también se diera la respuesta entusiasta de un público más exigente, como el teatral, era preciso contar con sólidos argumentos y, sobre todo, con unas ideas claras acerca de los objetivos y los medios.

El objetivo ideal del grupo, supongo, era crear espectáculos cuyo elemento fundamental fuera el humor, destinado a un público amplio y diverso, sin dejar- 
se deslizar por los caminos trillados u oportunistas ni caer en la sal gruesa. Un humor a menudo calificado por la crítica como blanco, sutil, inteligente..., pero que en definitiva respondía a lo que a ellos, como espectadores, les divertiría ver $y$, como actores, interpretar.

La realidad de sus inicios, más prosaica, estaba limitada por la posibilidad de actuar en pequeños locales no específicamente teatrales, donde lo adecuado era presentar uno o varios sketchs que no requirieran una escenografía propia. Expresión corporal, vestuario, máscaras, algunos objetos... eran sus útiles para trabajar en cualquier espacio. La formación como mimos y payasos de los integrantes de Tricicle constituia la base, que en Manicòmic adaptaron a las exigencias de su momento, donde ya no tenía demasiado sentido aparecer con las típicas mallas negras en contraste con la blancura del rostro y las manos. Eso sí, las redondeadas narices rojas las mantuvieron y hasta las volverían a utilizar, esporádicamente, en otros espectáculos.

Manicòmic es una estación de tránsito entre el trabajo realizado a base de sketchs independientes y la preparación de un espectáculo teatral. Se presenta como tal, pero, a diferencia de lo que será habitual en los posteriores, apenas encontramos un hilo conductor -esta función se encomienda a un sexto sketch, protagonizado por Carles Sans como presentador de los otros cinco-e, incluso, uno de ellos, Gags, responde literalmente a su título, pues es una mera sucesión de gags, a los que tanto recurrirán en su posterior trayectoria tanto teatral como televisiva. Tricicle había dado el salto a un circuito teatral, pero con un bagaje que denotaba un origen alejado de lo representado habitualmente en dicho circuito.

Aunque en Manicòmic todavía observamos reminiscencias, pocas y hasta irónicas, de una concepción clásica del mimo, Tricicle ya se decanta por la pantomima dada su adecuación al objetivo humorístico. Y lo hace, desde el principio, optando por un eclecticismo nada purista, que permite la inclusión de las máscaras -ausentes en los espectáculos posteriores-o de rasgos propios de otras técnicas, como la del clown revitalizada por figuras como Jango Edwards. El sonido (onomatopeyas, ruidos...) también aparece, aunque con una timidez que iría dejando paso a su evidente eficacia humorística. Asimismo, las referencias musicales y cinematográficas pronto se hicieron presentes, iniciando una constante del grupo que le llevaría a colaborar con destacados compositores y, en el caso de las segundas, sería decisiva en múltiples aspectos. Todo era necesario para actualizar un humor que pretendía llegar a un público más amplio que el habitual en los espectáculos de mimo y similares, todavía tan escaso como minoritario salvo honrosas excepciones.

Los miembros de Tricicle nunca han descuidado su técnica interpretativa. Desde su primer espectáculo han evidenciado una buena formación, que les ha permitido resolver con aparente sencillez las exigencias de una expresión cor- 
poral que requería una comprensión inmediata por parte del espectador. La han depurado poco a poco, siempre a la búsqueda de una mayor concisión y precisión que han alcanzado con una disciplina sin alardes. De acuerdo con un esquema habitual en los grupos humorísticos, cada uno de los tres actores se ha especializado en una gama de tipos en función, básicamente, de sus características físicas y unas determinadas posibilidades gestuales. Esta circunstancia, sin caer en lo previsible de un reparto fijo al modo de otros grupos, les ha dado una gran fluidez para recrear multitud de tipos a lo largo de cada espectáculo, siempre complementarios y sujetos al necesario contraste para lograr el efecto humorístico.

Rapidez, agilidad, ritmo... son los rasgos de una técnica interpretativa cada vez más sobriamente utilizada, hasta llegar a grados de estilización como los de Sit o els increibles homes cadira (2002). Su objetivo, no obstante, ha estado siempre más cerca de la eficacia que de la pureza, concepto un tanto inútil dados los planteamientos del grupo. Sus miembros contaban con la necesaria formación y, sobre todo, con una capacidad de observación y asimilación, presente en numerosos detalles de sus espectáculos que, pertinentemente utilizados, han propiciado una comunicación inmediata y fluida con los espectadores. También cálida -la cuarta pared nunca ha sido una frontera para Tricicle- y dosificada, con un sentido del ritmo imprescindible para la correcta representación de cada uno de los gags, siempre precisos y medidos. Incluso abundantes, no tanto en Manicomic como en otros espectáculos posteriores más deudores del ritmo trepidante de la televisión, contando, además, con la mayor rapidez del gag visual frente al que necesita de la palabra.

La experiencia acumulada ha permitido a Tricicle ahondar en estos rasgos ya presentes en Manicòmic, que sentó las bases del estilo del grupo. El éxito del mismo pronto tuvo imitadores, capaces de captar rasgos sueltos -sobre todo, en el campo de la gestualidad-, aunque sin cuajar en aportaciones similares o con la necesaria continuidad por falta de respuesta del público o un inadecuado enfoque empresarial. Estamos, pues, ante una situación insólita en un teatro como el humorístico, donde cada éxito viene sucedido de las inevitables imitaciones, no necesariamente rechazables. Tal vez, en este caso, dada su aparente sencillez, sea más complejo seguir la senda de Tricicle, que como empresa ya se ha encargado de que tenga continuidad a través de Clownic, un grupo que sigue representando los espectáculos ya estrenados bajo las directrices de sus creadores.

La trayectoria de Tricicle es una de las más brillantes del teatro español de la etapa democrática. Los éxitos se han sucedido desde el inicial de Manicòmic, que requería un inmediato paso adelante ante la inconveniencia de volver a montar un espectáculo a base de sketchs aislados y con diversas técnicas. Lo consiguieron en Exit (1984) -el primero de los que giran en torno a un espacio común: un aeropuerto, en este caso-, que les aportó la confirmación entre unos espectado- 
res que ya les seguían. La consolidación de un estilo propio y de su éxito vendría con Slastic (1986), donde el elemento unificador era una marca de artículos deportivos 5 . Desde entonces, el grupo siempre ha contado con el apoyo masivo de un público heterogéneo -hasta extremos sorprendentes en el actual panorama teatral-, que le ha permitido mantener en cartelera durante períodos prolongados cada uno de los espectáculos. También ha gozado del respeto casi unánime de la crítica periodística -a pesar de algún episodio aislado-, que ha puesto de relieve la profesionalidad y la coherencia del trabajo realizado por los integrantes de Tricicle. Si a estas circunstancias añadimos la frecuente, y a veces exitosa, presencia del grupo en televisión con series propias (Tres estrellas, 1987-1988; Chooof!, 1994...) y la menos afortunada incursión en el cine (Palace, 1995), nos encontramos con el grupo teatral español con mayor proyección popular ${ }^{\circ}$. También internacional, gracias a sus importantes y reiteradas giras por muy diversos países que han disfrutado con un lenguaje que, al igual que sucediera con el de los clásicos humoristas del cine mudo, traspasa con facilidad las fronteras.

Esta concatenación de éxitos les ha permitido contar con una capacidad de producción nada frecuente en una compañía privada. Montajes tan complejos como el de Terrific así lo prueban. El escenario casi vacío y neutro de sus inicios dio paso a un esfuerzo por afrontar el espacio, de manera que los espectadores no echaran de menos la palabra, innecesaria en un castillo propio de un parque de atracciones, donde se sucedían las divertidas peripecias de unos personajes cuya comicidad requería un conjunto de efectos especiales. Quedaban por entonces lejos los austeros tiempos de Manicòmic, pero la esencia de su humor permanecía inalterable. Así se ha mantenido hasta la actualidad, con un espectáculo tan maduro como Sit, donde incluso se vuelve, hasta cierto punto, a los orígenes con un bagaje enriquecido a lo largo de más dos décadas.

No estamos ante una actitud creativa inmovilista, anclada en unos principios inamovibles, sobre todo tras comprobar su eficacia de cara al público. Los integrantes de Tricicle nunca se han estancado en lo ya hecho. Al contrario, han probado su capacidad de iniciativa para abordar nuevos campos individual o colectivamente (televisión, cómic, cine, prensa, publicidad, radio...) y han diversificado una notoria actitud creativa, siendo en este sentido llamativa la trayectoria de Paco

${ }^{5}$ A estos espectáculos les sucederían: Terrific (1991), Entrerrés (1996), Tricicle 20 (1999) y Sit (2002). Todos los espectáculos han sido difundidos en soporte VHS y en DVD. El propio grupo ha publicado dos volúmenes donde recopila imágenes y testimonios de su trayectoria: Tricicle: 10 años y un dia, Barcelona, Edicions de l'Eixample, 1989 y Tricicle 20:1979-1999, Barcelona, Tricicle, 1999.

"El número de representaciones de sus espectáculos así lo prueba. Según fuentes del propio grupo, son: Manicòmic, 117: Exit, 300; Slastic, 597; Terrific, 576; Entretrés, 610 y Tricicle 20, 318. 
Mir, un destacado autor - su comedia No es tan fácil es un magnífico ejemplo-y director teatral. No se trata, pues, de conformismo o escasa voluntad creativa, sino de una coherencia con unos principios bien asentados desde los tiempos de Manicòmic.

La clave de su humor, que ha llegado a tantos y tan diversos tipos de espectadores, reside en una sabia combinación de elementos de heterogénea procedencia, a la que cabe sumar la diversificación creativa que supone la colaboración de tres autores tan distintos como complementarios. Nunca han buscado la pure$\mathrm{za}-\left\langle\langle\text { Nadie nos ha podido catalogar. Somos una mezcla de todo }\rangle^{{ }^{8}}\right.$, ni siquiera cuando todavía aparecían como unos mimos o unos payasos más o menos al uso. Tampoco la perfección exquisita en un arte siempre minoritario en nuestro país. Desde el principio, los miembros de Tricicle optaron por la mezcla de técnicas (la máscara, la pantomima...) para crear gags y scketchs que, por su propia naturaleza, escapaban del ya un tanto agotado mundo del clown y el mimo. Algunas, las más tradicionales y deudoras de su formación artística, como las máscaras, pronto desaparecieron de sus espectáculos. Suponían una limitación para una múltiple caracterización de tipos, un fregolismo cultivado con especial acierto, que debía ser resuelta mediante otras técnicas más cercanas al mundo de la televisión o el cine y, al mismo tiempo, compatibles con una teatralidad que siempre ha respetado Tricicle.

Los espectáculos de este grupo han sido un ejemplo de la tensión que debe presidir la creación teatral en la actualidad, en inevitable contacto con otros medios que la condicionan, la limitan y, al mismo tiempo, la enriquecen. Su trabajo fundamental siempre ha estado en los escenarios, pero también ha creado series televisivas que, a diferencia del locuaz humor costumbrista tan revitalizado en estas últimas temporadas, se centran en recursos como el gag visual, rápido, preciso y bien construido con un sentido del ritmo aprendido en los maestros del cine cómico mudo. Esta influencia, junto a otras, ha acabado trasladándose a sus espectáculos. Tras presentar un auténtico muestrario de técnicas teatrales en Manicòmic, no renunciaron a las mismas en términos absolutos, sino que las diluyeron en un

\footnotetext{
${ }^{7}$ Estrenada en Barcelona el 21 de diciembre de 1999, ha sido editada por la SGAE (Madrid, 2001 ) y, en formato digital, por cervantesvirtual.com.

" Declaraciones de Carles Sans a La Verdad, de Murcia (9-X-2004). Esta capacidad para combinar elementos heterogénos ya fue subrayada por la crítica desde el estreno de Manicòmic. Josep Urdeix, en su reseña publicada en El Correo Catalán (17-XII-1982), afirmó: «Tricicle ha optado por lo que podía ser eficaz, por lo que podía conseguir llevarse el público al bolsillo y hacerlo con regocijo de todos. Aquí hay un poco de todo. Un poco de mimo, un poco de pantomima, un poco del relato gestual sin necesidad de palabras, un bastante de imaginación para sacarle chispa a lo más cotidiano y un mucho de relajante humor para producir risueñas sorpresas de la manera más elemental. Pcro, por encima de todo, hay un saber estar en el escenario con soltura y afianzamiento».
} 
contacto con otras de origen televisivo y cinematográfico, cada vez más presentes en sus obras hasta llegar a su, en mi opinión, mejor plasmación: Entretrés, considerada por el grupo como «una telecomedia»-el espectáculo incluía cinco episodios de la misma-, protagonizada por tres artistas incomprendidos que comparten un pequeño apartamento. Tal vez por esa misma razón hayan vuelto en Sit a una especie de reteatralización, aunque siempre en una estrecha relación con otros medios audiovisuales que no choca ni sorprende, que se resuelve con naturalidad y apenas deja ver las costuras tan molestas en otros grupos o intérpretes.

El origen de estas técnicas televisivas y cinematográficos es diverso y, probablemente, no estamos ante un caso de deliberada imitación de unos modelos seleccionados con este objetivo. Los miembros de Tricicle son espectadores, como su propio público; beben en las mismas fuentes que cualquiera de nosotros. En sus espectáculos no encontramos la referencia cinéfila o de una improbable erudición teatral, sino la recreación humorística de un archivo visual que comparten con la inmensa mayoría de su numeroso público. Nos hablan, a su manera, de experiencias comunes, propias de una memoria en donde realidad y ficción no suelen establecer límites estancos. La activamos cada vez que identificamos, con rapidez, algún detalle (un gesto, una actitud, un comportamiento...) del cual Tricicle extrae sus, a menudo, sorprendentes posibilidades cómicas. No tanto por la imitación como por una caricatura, siempre respetuosa, estilizada y creativa, donde interviene nuestra retina ya habituada a actuar como si fuera una cámara televisiva o cinematográfica. Juegan con ella y nos demuestran su viabilidad en un escenario teatral, de cuyas fronteras son conscientes desde los tiempos de Manicòmic. También es verdad, como sabemos, que lo bueno de cualquier frontera es su posibilidad de traspasarla.

El cine está presente en los espectáculos de Tricicle desde los tiempos de Manicòmic, cuando los náufragos de L'illa se empeñaban en ver películas del oeste o de terror en un imaginario televisor. Por entonces era una simple referencia temática, como tantas otras. Su influencia se incrementó y transformó en la medida en que el grupo, a partir de su primer éxito, fue desvinculándose del código de gestualidad de Marcel Marceau, su escuela compartida por tantos otros mimos de las últimas décadas del siglo Xx. Pero como manifestara el maestro, en su última visita a España con su alter ego, Bip, «la gramática del mimo ha cambiado». También gracias a aportaciones como la de Tricicle. En ese proceso podemos encontrar referentes explícitos como Jacques Tati o el clásico cine mudo norteamericano, admirados por los miembros del grupo, siempre atentos a los maestros del gag y la gestualidad -también los más cercanos a su generacional formación como espectadores, Peter Sellers y Jerry Lewis, por ejemplo-, en una renuncia a la palabra que nunca ha supuesto una merma de su eficacia comunicativa. 
Al mismo tiempo, en algunos detalles de la estructuración del efecto cómico también encontramos la influencia del cómic-cultivado con acierto por el polifacético Paco Mir en revistas como TBO (1979-1982) y El Jueves (1981-1999)-y, más en concreto, de los chistes sin palabras que casi siempre vemos publicados en la prensa. Y la televisión, por supuesto. Sus series, emitidas en varios países, son desiguales. Incluso, en una de las últimas, Dinamita, percibo un cierto agotamiento creativo, paralelo al alejamiento del origen teatral ${ }^{9}$, no compensado por la colaboración de otros guionistas. Tal vez la causa radique en un excesivo acomodamiento al medio televisivo, algo que no sucedía en las primeras: Tres estrellas y Chooof! $!^{10}$. En las mismas, Tricicle seguía actuando, desde el punto de vista creativo, como un grupo teatral, capaz de llevar a la pequeña pantalla un lenguaje fresco que por entonces tenía otros referentes, sobre todo en el ámbito anglosajón. Con menos vulgaridad que el rijoso protagonista de Benny Hill y más ritmo que $M r$. Bean, no cultivaban un humor basado en una reconocible mediocridad del individuo como el de Rowan Atkinson ni tan corrosivo como el de los Monty Python, pero provocaron la sonrisa de millones de espectadores sin ceder un ápice en nombre de lo fácil y rancio, que tanto ha abundado en otras series humorísticas nacionales, ajenas al peculiar tratamiento narrativo que tenian las citadas.

La porosidad demostrada por Tricicle ante las manifestaciones culturales contemporáneas es compatible en su caso con el respeto por la tradición teatral, que han sabido actualizar e interiorizar como ya lo hicieran otros mimos. Han ido prescindiendo de las mallas, las caras pintadas, las narices rojas, las máscaras, la gestualidad de Marcel Marceau..., pero de manera más superficial que profunda. Lo citado, más todo lo que formó parte de su formación como mimos ejemplificada en Manicòmic, se ha diluido en una técnica peculiar, cuya aparente sencillez esconde un trabajo consciente en la búsqueda de la eficacia comunicativa. La alcanzan con una soprendente seguridad y facilidad, gracias a la experiencia de un grupo que lleva años sin bajarse de los escenarios, creando en comunión con unos espectadores que tan decisivos han sido en la definitiva configuración de sus espectáculos. Este privilegio, insólito en nuestro panorama teatral, lo han aprovechado para eliminar lo obvio de sus deudas, interiorizarlas y crear un estilo peculiar.

Los integrantes de Tricicle saben que sus espectadores están sometidos a un auténtico zapping cultural, que en su imaginario coexisten referencias cinematográficas, televisivas, musicales..., cuya mezcla resulta a veces un tanto caótica.

\footnotetext{
"Fsta circunstancia no ha impedido que una antología de los gags haya servido para crear un homónimo espectáculo teatral, estrenado en Barcelona (Teatro Victoria) en otoño del 2004.

${ }^{10}$ Entre ambas, se encuentra La troupe de Cobi (1990), que tuvo menor difusión y no tuve la ocasión de ver.
} 
Sus espectáculos parten de esta realidad, compartida por unos creadores cuyos centros de interés también se reparten en diferentes medios. En Manicòmic pusieron en escena su bagaje, pero en los posteriores lo utilizaron, junto con otros asimilados, para crear a partir de un espacio: un aeropuerto, un castillo de los horrores, un apartamento... O un objeto de uso cotidiano y universal: las sillas. Motivos sobre los que han volcado una indudable capacidad creativa basada en la observación - «Planteamos siempre situaciones de la vida cotidiana y mostramos personajes que no se alejen mucho de lo real» ${ }^{11}-\mathrm{y}$, claro está, la manipulación de lo observado para provocar el efecto humorístico, allí donde no parece estar y puede deparar una mayor sorpresa.

El arte del mimo es inútil si no parte de la observación. Tricicle, junto con otros grupos coetáneos, ha roto fronteras tradicionales en dicho arte mediante una gestualidad más espontánea, que renuncia al símbolo y la dimensión poética, así como la inclusión de recursos sonoros y visuales. Música, voces en off, una escenografia cada vez más rica y compleja... van en esa dirección, pero siempre a partir de una atenta observación que, una vez enriquecida por el humor, comparten con el espectador. Observación de una realidad cotidiana y menuda, donde se mezcla lo vivido con lo visto, bien en directo o como espectador televisivo o cinematográfico.

Pongamos algunos ejemplos. En Manicòmic, uno de los sketchs es el titulado Ecs, donde una serie de tipos realiza una acción tan cotidiana como depositar una bolsa de basura en la calle. Observamos un esquema argumental tradicional en el teatro cómico: el desfile de tipos que protagonizan una misma acción. La utilización de máscaras, un vestuario bien seleccionado y una expresión corporal que subraya lo esencial permiten que, en apenas unos instantes, captemos lo peculiar de cada uno en su relación con dicho acto cotidiano. Una bolsa de basura se puede depositar con melancolía o deportivamente, con mimo o desprecio... Se convierte así en una reiterada referencia capaz de sintetizar una caricaturesca definición de cada tipo. Como tal, es rápida y propicia el ritmo de un desfile donde el contraste es continuo. Provoca de esta manera la risa del espectador, quien, al final, se olvida de lo cotidiano y vulgar del acto recreado, porque ya no lo es gracias a la perspectiva humorística.

Junto a este sketch, encontramos otros donde la observación de la cotidianidad supone un contraste en un marco argumental cuyo origen pertenece al ámbito de la ficción. Un ejemplo sería L'illa, que daría origen a la serie televisiva Chooof!. En ambos casos, Tricicle parte de una situación reconocible por cualquier lector de las viñetas cómicas publicadas en revistas y periódicos: la isla solitaria poblada

\footnotetext{
"Declaraciones de Carles Sans a La Verdad, de Murcia (9-X-2004).
} 
por un náugrafo con barba, harapos y pacientemente sentado bajo una palmera. El humor, como tantas veces, proviene del contraste entre esta situación ficticia y la inserción de elementos de una cotidianidad estilizada por la mímica. Los náufragos, en tan estrecho marco, pretenden ducharse, ver la televisión, jugar al escondite..., en un empeño imposible que provoca la sonrisa del espectador.

Podrían haber acumulado otros sketchs en un nuevo espectáculo, con el riesgo de la reiteración. Lo evitaron al emplear estas técnicas en un marco que contaba con un esquema argumental mínimo, pero unificador. Esta circunstancia, un mero punto de partida, les aportó mayor flexibilidad para buscar un humor donde lo aprendido y mostrado en Manicòmic también se hace presente. En todos los espectáculos de Tricicle, por ejemplo, encontramos desfiles de tipos que comparten una misma situación. No ya como un sketch independiente, sino integrado en el desarrollo argumental. Y, por otra parte, el contraste entre la realidad cotidiana y la imaginación también alumbrará algunos de los momentos de más brillante creatividad del grupo. Su manipulación de objetos vulgares transformados en lo más insospechado se muestra, por ejemplo, en Entretrés, donde un aspirador se convierte en un avión pilotado por la mujer de la limpieza o unas tapas de inodoro se multiplican a la hora de transformarse en una galería de objetos ficticios que divierten a quienes, de otra manera, iban a pasar una aburrida tarde de domingo. En definitiva, nunca se renuncia a lo puesto en escena en Manicòmic, sino que se presenta evolucionado, diluido en un nuevo marco, insertado en un esquema más complejo que se acerca al mundo de la comedia, con evidentes influencias televisivas, pero sin traspasar los límites de la teatralidad.

Tricicle es un grupo de ya larga trayectoria, algo insólito en nuestro panorama teatral donde la voluntad de un individuo como Albert Boadella es capaz de aglutinar los cuarenta años de Els Joglars, pero con frecuentes cambios de actores. Algo similar sucede con Joan Lluis Bozzo y Dagoll Dagom. También es larga la trayectoria de su humor, hasta tal punto que espectáculos como Tricicle 20 han podido volver a mostrar antiguos sketchs con renovado éxito. Las claves de la permanencia del grupo habría que buscarlas en una buena y profesional organización, sin voluntad de liderazgo en sus miembros, con unas cuantas reglas y unos papeles conscientemente asumidos por unos intérpretes disciplinados, dentro y fuera del teatro, aunque hayan reivindicado una anarquía creativa e instintiva que cuesta creer a la vista de la perfección alcanzada. Las claves de la permanencia de su humor cabe relacionarlas con un rechazo de la parodia o la sátira de la actualidad, incluida la política, que nunca les ha interesado. Paco, Carles y Joan buscan referencias en la realidad concreta e inmediata de una cotidianidad próxima a la nuestra, pero pocas veces se quedan en lo superficial, saben extraer lo fundamental de unos tipos o unos comportamientos con unas posibilidades cómicas que van más allá del momento fugaz en que son captados. Son reconocibles por 
sus coetáneos, pero lo siguen siendo unos años después sin apenas cambiar algo sustancial. Es, pues, un humor clásico, no tanto por sus objetivos como por sus técnicas, que evitan la copia fácil y se plantean la búsqueda del contraste, de lo imprevisto, en una realidad cotidiana repleta de posibilidades cómicas al alcance de quien la observe con la creatividad demostrada por Tricicle.

También es un humor con vocación universal, que reivindica el esperanto visual de los maestros cómicos del cine mudo. Sus espectáculos son capaces de provocar la sonrisa de las personas más dispares, siempre que mantengan fresca su capacidad de sorprenderse e imaginar, incluso una cierta candidez. Apenas sabemos algo, públicamente, acerca de las opiniones de los integrantes de Tricicle, disciplinados también a la hora de permanecer en un relativo anonimato que, en este sentido, resulta adecuado para su proyección como grupo teatral. Sus intervenciones públicas son siempre medidas y cuando los individuos pasan a un primer plano, como es el caso de las colaboraciones periodísticas de alguno de ellos, dejan atrás su vinculación con Tricicle y firman con su nombre y apellidos, sin más. Consiguen así preservar la imagen de un grupo cuya coherencia, paradójicamente, les ha llevado a una popularidad y a una comercialidad que, en su caso, distan mucho de ser factores devaluadores de su calidad.

El humor de Tricicle es necesario, compatible con otros de características muy diferentes. Podemos sonreír con ellos al mismo tiempo que disfrutamos con grupos e intérpretes que cultivan la sátira, lo corrosivo, lo irónico..., incluso en sus manifestaciones más extremas. También, probablemente, más fugaces por estar en muchos casos relacionadas con fenómenos de actualidad, caducos por su propia naturaleza. Frente a ellos, los espectáculos del grupo catalán han aportado más de dos décadas de un humor teatral cuyas raíces fueron mostradas en Manicòmic. Raíces hundidas en lo clásico, cuya actualización con imaginación y creatividad ha permitido que en la España democrática surgiera, al menos, un exitoso y permanente ejemplo teatral alejado de la vulgaridad, la chabacanería y lo anquilosado de tantas manifestaciones humorísticas que habían poblado los escenarios españoles. Hoy se han trasladado, algo remozadas, a la televisión, algunas todavía permanecen en las carteleras bajo engañosos titulos.com de aparente modernidad, pero contamos con un ejemplo positivo que demuestra que el humor puede triunfar sin deslizarse por el camino de lo fácil.

Conviene recordarlo, y hasta reivindicarlo. En un teatro como el de la etapa democrática, tan acuciado por los problemas y sumido en el eterno concepto de crisis, sorprende que los pocos motivos de satisfacción queden un tanto marginados, tal vez porque rompen los esquemas de unos críticos que se regodean en el fracaso o quedan fuera de lo considerado «serio» por parte de los investigadores universitarios. Siempre he admirado el éxito, de cualquier tipo, sobre un escenario. Incluso la comercialidad, que en el caso de Tricicle sólo proviene de 
un público satisfecho que, con su apoyo, ha permitido que nos encontremos ante algo tan insólito como una compañía que se autofinancia al cien por cien. Otros hablan de un teatro quimérico, imposible, fracasado, de espaldas a los espectadores... Yo prefiero el que, con sencillez que tanto cuestiona, se dirige a los mismos con los resortes de una tradición actualizada, con la seguridad aportada por unas técnicas que provocan un humor que necesitamos y merece la pena almacenar en la memoria. Tricicle nos ha ayudado en esta tarea individual y colectiva desde los tiempos de Manicomic, los que coinciden con una etapa democrática donde ha sido necesario superar un humor rancio que siempre nos amenaza. 